\title{
Physico-Chemical Characterization of Industrial Liquid Discharges of Soap Factories in Abidjan, Côte D’Ivoire
}

\author{
Jean Missa Ehouman', Bernard 0. Yapo ${ }^{2,3}$, Agness Essoh Jean Eudes Y. Gnagne², Nahossé Ziao ${ }^{*}$ \\ ${ }^{1}$ Laboratory of Thermodynamics and Physical Chemistry of the Environment, (UFR-SFA), UNA, Abidjan, Côte d'Ivoire \\ ${ }^{2}$ Laboratory of Environmental Sciences, (UFR-SGE), UNA, Abidjan, Côte d'Ivoire \\ ${ }^{3}$ The Central Environment Laboratory of the Ivorian Anti-pollution Center, Abidjan, Côte d'Ivoire \\ Email:*ziaonah_sfa@una.edu.ci
}

How to cite this paper: Ehouman, J.M., Yapo, B.O., Eudes Y. Gnagne, A.E.J. and Ziao, N. (2017) Physico-Chemical Characterization of Industrial Liquid Discharges of Soap Factories in Abidjan, Côte D'Ivoire. Journal of Geoscience and Environment Protection, 5, 198-210.

https://doi.org/10.4236/gep.2017.58016

Received: June 21, 2017

Accepted: August 4, 2017

Published: August 7, 2017

Copyright ( 2017 by authors and Scientific Research Publishing Inc. This work is licensed under the Creative Commons Attribution International License (CC BY 4.0).

http://creativecommons.org/licenses/by/4.0/

\begin{abstract}
This work deals with the efficient management of industrial liquid discharges from soap factories (ILDS) in the region of Abidjan. The aim of this work is to evaluate the physico-chemical quality of these discharges as well as the different types of pollution generated. Seventeen (17) industrial soap sources were studied through fourteen (14) global pollution parameters ( $\mathrm{T}, \mathrm{pH}$, electrical conductivity $\mathrm{EC}$, redox potential $\mathrm{E}_{\mathrm{H}}$, suspended matter $\mathrm{SM}, \mathrm{COD}, \mathrm{BOD}_{5}$, biodegradability factor $\mathrm{BF}, \mathrm{NH}_{4}^{+}, \mathrm{NO}_{2}^{-}, \mathrm{NO}_{4}^{-}, \mathrm{PO}_{4}^{3}$, total iron and $\mathrm{SO}_{4}^{2-}$ ). A liquid waste collection campaign was done during six weeks from February to March 2016, corresponding to a period of intensive activity of these industries. The samples were analyzed according to the norms of the French Standardization Agency (AFNOR). Results were compared with the Ivorian guide values recommended by the Classified Installations Inspection Service (CIIS). Principal Component Analysis (PCA) is allowed to evaluate the pollution induced by these factories' rejection. In addition, Ascending Hierarchical Classification (AHC) method leads to classify soap factories into three groups according to the physico-chemical quality of their releases. Moreover, the estimation of the biodegradability factor is permitted to know the state of the biodegradability of these effluents.
\end{abstract}

\section{Keywords}

Biodegradability, ILDS, Pollution, Soap Industries

\section{Introduction}

Abidjan City gathers up to $85 \%$ of industries settled in Côte d'Ivoire, because of 
its lagoon and sea assets. These industries are localized in various areas of the different industrial zones [1]. Despite Ivorian government's efforts to protect the environment, very few industries do follow its recommendations [2]. The use of water in the production process generates a huge volume of rejected liquid heavily loaded with oxidable materials [3] [4]. The increase of soap industries is due to the increase of human beings needs in term of soap, detergent and cosmetic. And this soap factories growth participates to this ecological disaster. These soap factories, like the other industries, are mainly concentrated in the area of Abidjan. They contribute to the production of enormous volume of effluents in Abidjan area. The characterization of ILDS in Côte d'Ivoire remains less established to date. This fact confers a certain scientific interest on these discharges. That is why more complete physicochemical characterization constituted the first step to be taken into account in order to estimate the level of pollution of this type of industrial waste.

\section{Experimentation Method}

\subsection{Area of Study and Location of Soap Factories}

The area of Abidjan has a fluvial network of $89.81 \mathrm{~km}^{2}$ of lagoon, which is equivalent to $16 \%$ of its area [5] with an estimated population of 4,693,912 [6]. The seventeen soap factories targeted are those which throw directly their rejection into the lagoon. The mapping of the studied area (Figure 1) shows the different industrial areas, the location of the studied soap factories and the river system of Abidjan's town.

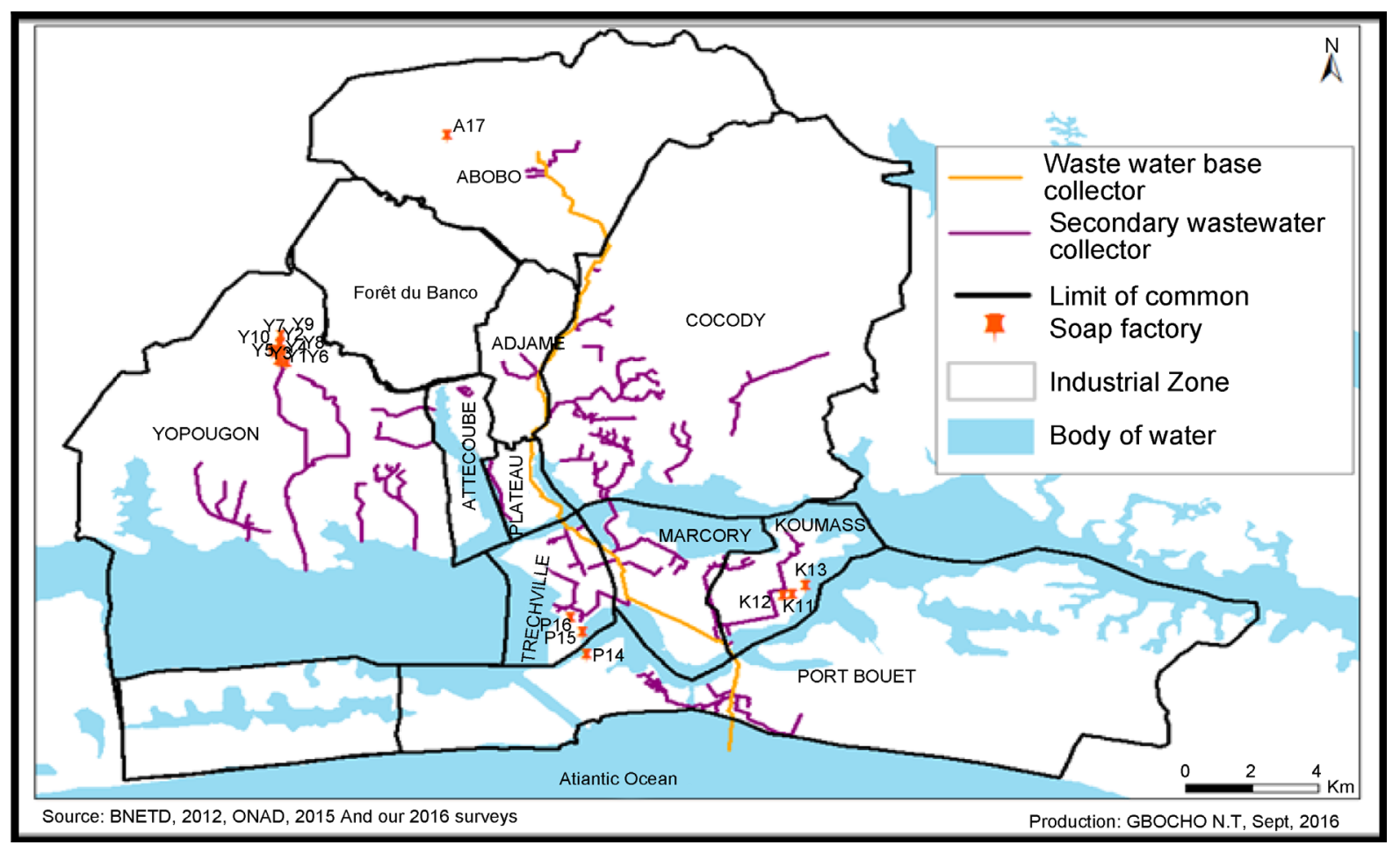

Figure 1. Mapping of the study area and location of soap factories. 


\subsection{Sampling Method}

Samples have been collected in the seventeen factories at the level of the outlet before rejection of soap factories in polyethylene and put in glass bottles (for total iron parameter). Bottles are washed with distilled water before collecting process. Then collected samples are labelled, conserved at temperature of $4^{\circ} \mathrm{C}$ and kept away from light in ice-box. Finally samples are analyzed the same day as soon as possible in order to avoid any bacterial activity. This sampling has been done during six (6) weeks from February to March, 2016. This period corresponds to the highest level of the production of soap factories.

\subsection{Analysis Method}

Physical parameters such as temperature, $\mathrm{pH}$, redox potential and electrical conductivity were measured by electrometry in situ using a HACH HQ $40 \mathrm{D}$ multiparameter probe. Ammonium, nitrite, nitrate, sulphate, ortho-phosphate, chemical oxygen demand (COD), and the total iron rate were measured through molecular absorption using a HACH/DR 6000 spectrometer. The Biochemical Oxygen Demand $\left(\mathrm{BOD}_{5}\right)$ was measured by oximetry using an Oxitop ${ }^{\circ}$ WTW oximeter. Finally, the analysis of suspended matter (SM) was carried out through filtration/gravimetry with the WHATMAN filters. All these analyses were done according to the methods of the French Standardization Agency AFNOR [7]. The data collected were treated using statistical approaches such as the correlation coefficient, Principal Component Analysis (PCA) and Ascending Hierarchical Classification (AHC) [8]. Statistical treatments were carried out using the Statistica 7.1 software.

\section{Results and Discussions}

\subsection{Physical Characterization of Industrial Liquid Discharges of Soap Factories (ILDS)}

Table 1 presents the results of the characterization of the physical parameters of ILDS. Samples P16 and Y6 show the extreme temperature values of $25.4^{\circ} \mathrm{C}$ and $39.0^{\circ} \mathrm{C}$ respectively. All the measured values are lower than $40^{\circ} \mathrm{C}$, thus respecting CIIS recommended temperature in the case of discharge of effluents towards environment [9]. The highest and lowest $\mathrm{pH}$ values have been found in the soap effluent $\mathrm{K} 13$ and $\mathrm{Y} 2$, respectively. The high alkaline $\mathrm{pH}$ values recorded in $29.00 \%$ of the soap factories studied can be explained by the different activities related to the use of alkaline agents (caustic soda and potash) in soap formulation.

In fact, this essential raw material impacts, at several levels, the system of detergent's products formulation. First, the fatty acids are saponified by caustic soda or potash. In addition the lye (soda solution) is used for the operation of the hypo-lye. The rejections resulting from these operations, coupled with washing water of the soap, constitute effluents heavily loaded with hydroxide ions, which changes the $\mathrm{pH}$ of these discharges into alkaline. For soap factories with medium $\mathrm{pH}$ discharges, two explanations can be provided: The first is that 
Table 1. Physical parameter values.

\begin{tabular}{|c|c|c|c|c|c|}
\hline Stations & $\mathrm{T}\left({ }^{\circ} \mathrm{C}\right)$ & $\mathrm{pH}$ & $\mathrm{EC}(\mu \mathrm{S} / \mathrm{cm})$ & $\mathrm{E}_{\mathrm{H}}(\mathrm{mV})$ & $\mathrm{SM}(\mathrm{mg} / \mathrm{L})$ \\
\hline Y1 & 29.9 & 7.32 & 441 & -16.7 & 2060 \\
\hline Y2 & 31.1 & 5.13 & 40 & 115.1 & 214 \\
\hline Y3 & 29.7 & 7.16 & 741 & -6.9 & 2040 \\
\hline Y4 & 30.4 & 12.37 & 17270 & -319.4 & 25 \\
\hline Y5 & 30.5 & 6.62 & 495 & 24.5 & 26 \\
\hline Y6 & 39 & 7.75 & 682 & -43.6 & 51125 \\
\hline Y7 & 28.3 & 7.42 & 1992 & 23.7 & 6200 \\
\hline Y8 & 27.5 & 10.31 & 1737 & -193.9 & 220 \\
\hline Y9 & 28.2 & 12.58 & 14640 & -330.6 & 1284 \\
\hline Y10 & 29.7 & 6.38 & 76.4 & 21.4 & 4 \\
\hline K11 & 31.5 & 9.74 & 957 & -162.6 & 260 \\
\hline K12 & 30 & 5.27 & 645 & 106 & 2365 \\
\hline K13 & 32.1 & 13.47 & 138.4 & -387.6 & 1570 \\
\hline P14 & 30.1 & 6.61 & 599 & 26.3 & 10384 \\
\hline P15 & 28 & 7.84 & 463 & -47.5 & 80 \\
\hline P16 & 25.4 & 8.10 & 63 & 82 & 6.8 \\
\hline A17 & 32.3 & 6.12 & 570 & 55.5 & 588 \\
\hline $\mathrm{VG}^{*}$ & $<40$ & $5.5-9.5$ & - & - & 150 \\
\hline
\end{tabular}

VG*: Guide values referring to the lowest daily flow rates 01164 / MINEEF / CIAPOL / CIIS of 04 November 2008 [9].

these soap-making plants do not carry out saponification in their premises. They import soap paste bells for their productions. The second explanation comes from the fact that soap-making plants with weakly alkaline or neutral waste, the saponification is made with triethanolamine, which is a weak base organic alkaline agent. It should be noted that all these soaps produced by factories are used as toilet soaps with low $\mathrm{pH}$ value. In other way, it has been shown that $12.00 \%$ of the studied soap factories rejected water discharge with acid $\mathrm{pH}$. These soap-making factories produce others commodities such as water of cleaning (bleach) and cosmetics products.

Analysis of the Electrical Conductivity (EC) of soap effluents reveals a fluctuation of the values of this parameter. The high values of this parameter are observed in effluents from the soap mills (Y4, Y9) in Yopougon area. The Y4 soap effluent recorded the highest value $(17,270 \mu \mathrm{S} / \mathrm{cm})$. The lowest value $(40 \mu \mathrm{S} / \mathrm{cm})$ was observed in the Y2 soap rejection (Table 1). Correlation's analysis between physico-chemical parameters (Table 2) reveals a strong positive correlation of conductivity with nitrates $(0.90)$, ortho phosphates $(0.69)$ and, to a lesser extent, with nitrites $(0.62)$. This high mineralization is therefore due to the oxidation of these nutrients in the soap effluent. The oxidation-reduction potential value ranges from $-387.6 \mathrm{mV}$ (soap-making K13) to $115.1 \mathrm{mV}$ (soap-making Y2) (Table 1). $76 \%$ of these releases have a reducing character with redox 
Table 2. Correlation matrix of the physicochemical parameters of all the ILDS.

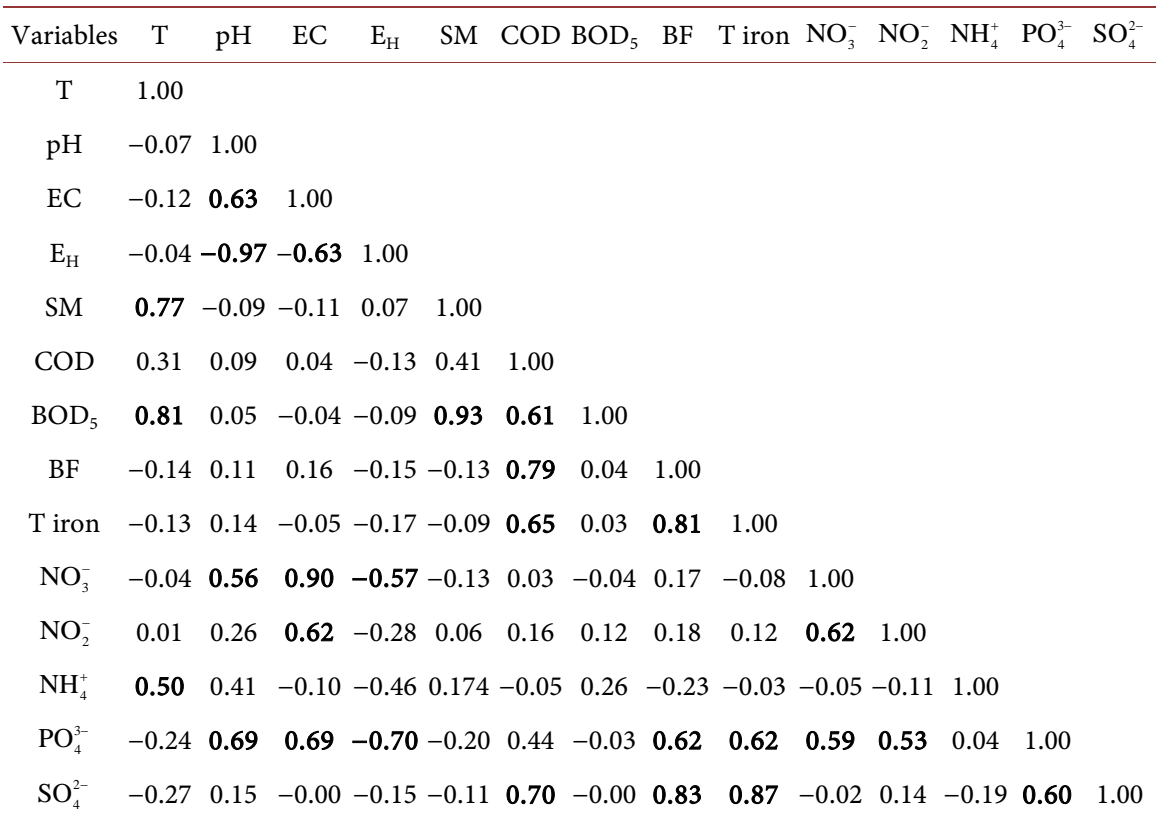

In bold, significant values at the alpha threshold $=0.050$.

potentials negative or less than $40.0 \mathrm{mV}$ [10]. These reductive soap discharges contain mainly aldehydes, organic compounds exhibiting reducing properties, resulting from the oxidation of compounds such as glycerols, polyphenols and polyalcohols used for the formulation of detergents and cosmetics [11]. The oxidation of the alcohol functions into aldehydes and the different oxidation-reduction reactions which result, use the oxygen of the receiving environment. Furthermore, the negative correlation of the oxidation-reduction potential with nitrates $(-0.57)$, ortho-phosphates $(-0.70)$ and conductivity $(-0.63)$ explains the reverse evolution of these parameters with the redox potential. The reducing properties of soap effluents allow the oxidation of nitrates and ortho-phosphates. The mineralization is due to this oxidation. These oxidation reactions reduce oxygen concentrations in the receiving environment, so that affects aquatic life [12]. The analyzed concentrations of Suspended Matter (SM) are irregularly distributed (Table 1). Some soap factories have high SM concentrations that exceed 4 to 341 times the guide value $(150 \mathrm{mg} / \mathrm{L})$. The very high SM content of these discharges is due to mineral and organic raw materials used in the formulation of their products. These industries, specialized in the formulation of cosmetic products according to our investigation, use excipients and active ingredients (fatty acids, glycerol, surfactants, polyalcohols etc.) as raw materials. The strong positive correlation of suspended matter with $\mathrm{BOD}_{5}(\mathbf{0 . 9 3})$ (Table 2) confirms the biodegradable organic origin of these SM in liquid soap discharges from soap industries. Moreover, this parameter is positively correlated with the temperature $(\mathbf{0 . 8 1})$ (Table 2).

The temperature favors the degradation of suspended organic matter in soap effluents. That damages the different receiving environments. Indeed, SM in a 
lagoon environment reduce the penetration of light into the water, consequently reduce the photosynthesis of phytoplankton under water, and dissolve oxygen in the aquatic environment. This causes faunal and aquatic floristic mortality by asphyxia [12]. In addition, SM conveys various chemical elements into the aquatic environment. The high concentrations of this parameter, generated by soap discharges, can be seen as a factor of pollution of the Ebrié lagoon [13].

\subsection{Chemical Characterization of Industrial Liquid Discharges of Soap Factories (ILDS)}

The analysis' results of chemical parameters are recorded in Table 3 below.

The analyzed ammonium concentrations of the ILDS range from $1.40 \mathrm{mg} / \mathrm{L}$ to $75.80 \mathrm{mg} / \mathrm{L}$ The highest value corresponds to the soap factory K11 (Table 3). In general, these soap factories use nitrogenous compound such as anionic surfactants (ammonium dodecyl sulphate), cationic surfactants such as bactericides (cetyltrimethylammonium bromide) and azo derivatives dye (Naphtol Blue Black: NBB) as the colorant of detergents [14]. The ammonium ions come from the degradation of these azo dyes. This degradation generates $\mathrm{NH}_{4}^{+}$cations due to the conversion of the nitrogen of the azo bond and the thriazine cycle into ammoniums [14]. The degradation of cationic surfactants such as cetyltrimethylammonium bromide also justifies the presence of these ammonium ions. The nitrites concentrations have a minimum of $0.003 \mathrm{mg} / \mathrm{L}$ and a maximum of

Table 3. Concentrations of the chemical parameters analyzed in ILDS.

\begin{tabular}{cccccccccc}
\hline \multirow{2}{*}{ Stations } & \multicolumn{7}{c}{ Chemical parameter $(\mathrm{mg} / \mathrm{L})$} \\
\cline { 2 - 9 } & $\mathrm{COD}$ & $\mathrm{BOD}_{5}$ & $\mathrm{BF}$ & $\mathrm{NO}_{3}^{-}$ & $\mathrm{NO}_{2}^{-}$ & $\mathrm{NH}_{4}^{+}$ & $\mathrm{PO}_{4}^{3-}$ & $\mathrm{SO}_{4}^{2-}$ & $\mathrm{T}$ iron \\
\hline $\mathrm{Y} 1$ & 5760 & 900 & 6.4 & 21.8 & 0.03 & 12 & 0.7 & 22 & 0.5 \\
$\mathrm{Y} 2$ & 34,000 & 1700 & 20 & 1.3 & 0.006 & 8.9 & 0.1 & 500 & 3.1 \\
$\mathrm{Y} 3$ & 3700 & 800 & 4.6 & 21 & 0.9 & 17.2 & 13.2 & 30 & 6.2 \\
$\mathrm{Y} 4$ & 13,800 & 1000 & 13.8 & 350 & 1.4 & 14.9 & 47.7 & 230 & 1.5 \\
$\mathrm{Y} 5$ & 4030 & 750 & 5.4 & 0.9 & 0.012 & 12 & 1 & 36 & 0.13 \\
$\mathrm{Y} 6$ & 37,900 & 8000 & 4.7 & 3 & 0.51 & 34.4 & 0.6 & 1.5 & 2.4 \\
$\mathrm{Y} 7$ & 580 & 180 & 3.2 & 1.7 & 0.5 & 8.5 & 0.5 & 700 & 0.5 \\
$\mathrm{Y} 8$ & 51,300 & 1500 & 34.2 & 14.2 & 0.6 & 8.27 & 62.5 & 2300 & 36.9 \\
$\mathrm{Y} 9$ & 9170 & 1100 & 8.3 & 112 & 0.8 & 12.5 & 48.2 & 3.4 & 2.4 \\
$\mathrm{Y} 10$ & 15 & 11.25 & 1.3 & 1.1 & 0.026 & 7.41 & 0.6 & 1.5 & 0.3 \\
$\mathrm{~K} 11$ & 3800 & 850 & 4.5 & 12.1 & 0.3 & 75.8 & 22.8 & 90 & 5.5 \\
$\mathrm{~K} 12$ & 7340 & 1000 & 7.3 & 11.2 & 1.33 & 6.11 & 0.4 & 16 & 1.2 \\
$\mathrm{~K} 13$ & 5510 & 1500 & 3.7 & 20 & 0.003 & 54 & 5.7 & 1.5 & 0.6 \\
$\mathrm{P} 14$ & 8320 & 700 & 11.9 & 11 & 0.05 & 10.8 & 0.5 & 1.5 & 1.8 \\
$\mathrm{P} 15$ & 3400 & 800 & 4.3 & 4 & 0.04 & 15 & 0.1 & 1.5 & 0.015 \\
$\mathrm{P} 16$ & 119 & 42 & 2.8 & 0.024 & 0.003 & 1.4 & 2.28 & 1.5 & 0.015 \\
$\mathrm{~A} 17$ & 2690 & 280 & 9.6 & 0.002 & 0.06 & 21.7 & 0.9 & 1.5 & 12 \\
$\mathrm{VG}$ & 500 & 150 & & 50 & - & - & - & - & 5 \\
\hline
\end{tabular}


$1.400 \mathrm{mg} / \mathrm{L}$ (Table 3 ). It should be noted that $29.41 \%$ of the soap mills (Y3, Y4, Y8, Y9 and K12) have nitrites concentrations above the recommended guide values of $0.500 \mathrm{mg} / \mathrm{L}$. These soap factories use nitrated and nitrosated dyes $\left(\mathrm{X}-\mathrm{C}_{6} \mathrm{H}_{5}-\mathrm{NO}_{2}\right)$ which generate nitrates as a result of their degradation. As for nitrates, the contents fluctuate between $0.002 \mathrm{mg} / \mathrm{L}$ and $350.000 \mathrm{mg} / \mathrm{L}$. Soap factories Y9 and Y4 show similarities in terms of nitrates with very high contents (Table 3). The presence of nitrates is due, in part, to the use of nitrogenous compound in the formulation of detergents and cosmetics. They are azo, nitrated and nitrosated dyes, nitrogen-containing surfactants, adjuvants such as nitrilotriacetic acid (NTA: $\mathrm{C}_{6} \mathrm{H}_{9} \mathrm{NO}_{6}$ ), ethylene diamine tetraacetic acid (EDTA: $\left.\mathrm{C}_{10} \mathrm{H}_{16} \mathrm{~N}_{2} \mathrm{O}_{8}\right)$, triethanolamine $\left(\mathrm{C}_{6} \mathrm{H}_{15} \mathrm{NO}_{3}\right)$. These compounds release nitrate ions, ammonium and nitrite ions [15]. Ammonium and nitrite ions can be oxidized into nitrates. In the light of the analyses, it can be said that the soap effluents are relatively rich in nitrogenous nutrients. The quantities of ortho-phosphates vary from $0.100 \mathrm{mg} / \mathrm{L}$ to $62.500 \mathrm{mg} / \mathrm{L}$ (Table 3). Soap factories with concentrations of ortho-phosphates higher than $2 \mathrm{mg} / \mathrm{L}$ use raw materials rich in phosphorus elements as adjuvants or bleaching agents (sodium tripolyphosphates: $\mathrm{Na}_{5} \mathrm{P}_{3} \mathrm{O}_{10}$, sodium pyrophosphate: $\mathrm{Na}_{4} \mathrm{P}_{2} \mathrm{O}_{7}$, trisodium phosphate: $\mathrm{Na}_{3} \mathrm{PO}_{4}$ ) for the formulation of detergents and cosmetics, especially. These compounds containing the soluble inorganic phosphorus in solution are transformed into orthophosphates which come from the hydrolysis of phosphoric acid. Even in very small quantity, orthophosphates are harmful for the environment due to the fact that they are easily absorbed by the soil, polluting thereby well water and the ground-water sheet [16]. Based on the recorded values, all the soap factories are potential polluters in terms of orthophosphates. Despite its usefulness, phosphorus is forbidden in the formulation of detergent and cosmetic products [17]. In sum, soap discharges are rich in nutrients that can impact environment. Indeed, concentration of nitrogen ammoniacal $\left(\mathrm{NH}_{4}^{+}\right)$at about $1.2 \mathrm{mg} / \mathrm{L}$ in a hydro system, at $\mathrm{pH} 7.5^{\circ} \mathrm{C}$ and $15^{\circ} \mathrm{C}$, is toxic for fish fauna [18]. In addition, nutrient concentrations can lead to an increase of algal blooms and consequently the appearance of eutrophication phenomena when the concentration of $\mathrm{NO}_{4}^{-}$equals $0.03 \mathrm{mg} / \mathrm{L}$ and the concentration of phosphorus equals $0.01 \mathrm{mg} / \mathrm{L}$ [19]. The sulfate concentration contained in ILDS fluctuates between $1.5 \mathrm{mg} / \mathrm{L}$ and $2300 \mathrm{mg} / \mathrm{L}$. Soap factory Y8 has the maximum concentration of sulphate ions (Table 3 ). The factories those rejections contain a lot of sulfate are specialized in the formulation of colored toilet soaps, cosmetics (shampoos, toothpaste, mouthwash products, etc.). These soap and cosmetics industries use anionic surfactants such as sodium dodecyl sulphate (SDS: $\mathrm{C}_{12} \mathrm{H}_{25} \mathrm{SO}_{4} \mathrm{Na}$ ) in the formulation of their products, sulfonated surfactants, especially sodium dodecylbenzene sulphonate (DBS: $\mathrm{C}_{18} \mathrm{H}_{29} \mathrm{SO}_{3} \mathrm{Na}$ ) and sulfated inorganic pigments or coloring agent, ferrous sulfate $\left(\mathrm{FeSO}_{4}, 7 \mathrm{H}_{2} \mathrm{O}\right)$, zinc sulfate $\left(\mathrm{ZnSO}_{4}\right)$ and organic sulfur dyes. These sulfate ions come essentially from both the dissolution of the sulfated salts and the oxidation of the sulfide groups of the aforementioned surfactants and dyes [20]. The total iron concentrations in the 
ILDS range from $0.015 \mathrm{mg} / \mathrm{L}$ to $36.900 \mathrm{mg} / \mathrm{L}$ (Table 3). The total iron concentrations for some soap factories (Y3, Y8 and A17) are 1.24 to 7 times higher than the guide value $(5 \mathrm{mg} / \mathrm{L})$. These soap factories therefore use raw materials rich in iron ions. These soap factories use colored pigments such as iron oxide $\left(\mathrm{Fe}\left(\mathrm{NH}_{4} \mathrm{COO}\right)_{2}\right)$, the complex salt (ferric ferrocyanide or Prussian blue) and ferrous sulphate $\left(\mathrm{FeSO}_{4}, 7 \mathrm{H}_{2} \mathrm{O}\right)$ to color detergents and cosmetics. The iron ions in the liquid discharges of these soap mills therefore result from the dissolution of these inorganic dyes. Y8 soap effluent contains the highest concentration of sulfates and total iron. It mainly uses iron sulfate $\left(\mathrm{FeSO}_{4}, 7 \mathrm{H}_{2} \mathrm{O}\right)$ as a colorant for the formulation of their mostly cosmetic products. That can be explained by the strong positive correlation of sulfate ions with total iron (0.83) (Table 2). The Chemical Oxygen Demand (COD) concentrations in the soap discharges are considerably higher than the guide value $(500 \mathrm{mg} / \mathrm{L})$, except soap factories $\mathrm{Y} 7$, Y10 and P16. The soap factory Y8 has the maximum concentration $(51,300$ $\mathrm{mg} / \mathrm{L}$ ) which is 103 times the recommended guide value (Table 3). For 5-day biochemical oxygen demand $\left(\mathrm{BOD}_{5}\right)$, Y8 (1500 mg/L), Y2 (1700 mg/L) and Y6 $(8000 \mathrm{mg} / \mathrm{L})$ effluents have $\mathrm{BOD}_{5}$ concentrations ranging from 10 to 53 times the limit value of $150 \mathrm{mg} / \mathrm{L}$ (Table 3). Liquid waste from most soap factories are heavily loaded with oxidable organic and mineral matter. These high COD values derive from the use of organic raw materials (fatty acids, surfactants, glycerin, phenolic compounds, polyalcohols, nitrogenous and phosphorus compounds, colorants, etc.) in the formulation of detergents and cosmetics. Y2, Y6 and Y8 effluents are identified by their high COD concentrations. This fact is worrying and can be explained by the nature of the products manufactured by these industries. Indeed, these soap factories are specialized in the intense production of toilet soaps and cosmetic products (cream, ointment, shampoos, hair products etc.). However, the formulation of these products requires oils and fat products such as surfactants (anionic, cationic, and nonionic), polyalcohols, etc., as basic raw materials. Organic or inorganic synthetic dyes, conservative and antioxidants must be added to the basic components. All these oxidable organic materials contribute to the high COD observed concentrations. The significant correlation of this parameter with sulfate ions $(0.70)$, total iron $(0.65)$ and $\mathrm{BOD}_{5}$ (0.61) (Table 2) justifies this contribution to oxygen demand.

\subsection{Biodegradability of Industrial Liquid Discharges of Soap Factories (ILDS)}

Analysis of the biodegradability factors $\left(\mathrm{COD} / \mathrm{BOD}_{5}\right)$ of the effluents reveals that soap discharges have a $\mathrm{COD} / \mathrm{BOD}_{5}$ ratio ranging between 1.3 and 34 (Table 3 ). Only one soap factory $\left(\mathrm{Y} 10: \mathrm{COD} / \mathrm{BOD}_{5}=1.3<2\right)$ has a biodegradable effluent. Soap factory P16 has an average of biodegradable effluent $\left(\mathrm{COD} / \mathrm{BOD}_{5}=2.8\right)$ between 2 and 3 . Soap factories Y10 and P16 certainly have treatment station. Finally, $\mathbf{8 8 . 0 0 \%}$ of the soap factories show discharges that are difficult to biodegrade with chemical-dominant pollution $\left(\mathrm{COD} / \mathrm{BOD}_{5}>3\right)$, which is characteristic of the chemical industries. The strong correlation of the biodegradability fac- 
tor with sulfate ions $(\mathbf{0 . 8 3})$, total iron $(\mathbf{0 . 8 1})$, and orthophosphate ions $(\mathbf{0 . 6 2})$ (Table 2) corroborates this chemical pollution, leading to the difficult biodegradability of soap effluents. The difficult biodegradability of these discharges is partly related to the specific use of surfactants as the main raw materials in the formulation of detergents and cosmetics. These effluents, which are mainly difficult to biodegrade, damage the environment. In order to propose an appropriate treatment method, it is necessary to group the soap industries studied according to the type of pollution induced by their releases through a multivariate statistical analysis.

\subsection{Types of Pollution Generated by Industrial Soap Liquid Discharges}

The application of the Principal Components Analysis (PCA) on the whole data allowed to highlight similarities or oppositions between variables, and to locate the most correlated variables between them in order to locate the various pollution generated by the liquid rejections of soap factories in the zone of Abidjan. Table 4 reveals that the factorial design $\left(\mathrm{F}_{1}-\mathrm{F}_{2}\right)$ and $\left(\mathrm{F}_{1}-\mathrm{F}_{3}\right)$ respectively express $56.71 \%$ and $55.66 \%$ of the original variance of the groups of dots (Table 4 ). These three factors express $\mathbf{7 8 . 3 4 \%}$ of the explained variance thus releasing the maximum of information on the rejections of soap factories.

Correlation matrix between physicochemical parameters and the various factors reveals interesting correlations between these factors and some physicochemical parameters. Thus, the main component $\mathrm{F}_{1}$ defines a strong positive correlation with $\mathrm{pH}(0.71), \mathrm{E}_{\mathrm{H}}(0.72)$ and strong negative correlation with $\mathrm{EC}(-0.72)$, nutrients $\mathrm{NO}_{3}^{-}(-0.65), \mathrm{NO}_{2}^{-}(-0.61), \mathrm{PO}_{4}^{3-}(-0.92)$, sulfates $(-0.63)$, total iron $(-0.69)$ and biodegradability factor $\mathrm{BF}(-0.69)$. This principal component characterizes ILDS alcalins, mineral-bearing with a nutritive and chemical pollution. Moreover, the factorial axis $F_{2}$ defines a significant correlation with the temperature $\mathrm{T}(\mathbf{0 . 6 6})$, the chemical oxygen demand COD (0.77), the biochemical oxygen demand of $\mathrm{BOD}_{5}(\mathbf{0 . 8 1})$ and the suspended matter SM (0.75). This axis characterizes an organic pole of pollution. Finally the $\mathrm{F}_{3}$ factor exhibits a fairly degree correlation with the ions ammonium $(-0.55)$. This axis focuses a nutritive pollution caused by ammonium ion. It results from the analysis of the circle of community and the statistical units of factorial design $F_{1}-F_{2}$ and $F_{1}-F_{3}$ (Figure 2(a) and Figure 2(b)), four classes of effluents are rejected into the lagoon Ebrié and characterizing four groups of soap factories. Then Group 1 concerns ILDS rich in $\mathrm{BOD}_{5}$ and in SM, such as soap factory Y6; Group

Table 4. Eigenvalues and percentages of the variances expressed by the factors.

\begin{tabular}{cccc}
\hline Factors & Own values & \% Total variance & Accumulation \% \\
\hline $\mathrm{F}_{1}$ & 4.76 & 34.03 & 34.03 \\
$\mathrm{~F}_{2}$ & 3.17 & 22.68 & 56.71 \\
$\mathrm{~F}_{3}$ & 3.03 & 21.63 & $\mathbf{7 8 . 3 4}$
\end{tabular}




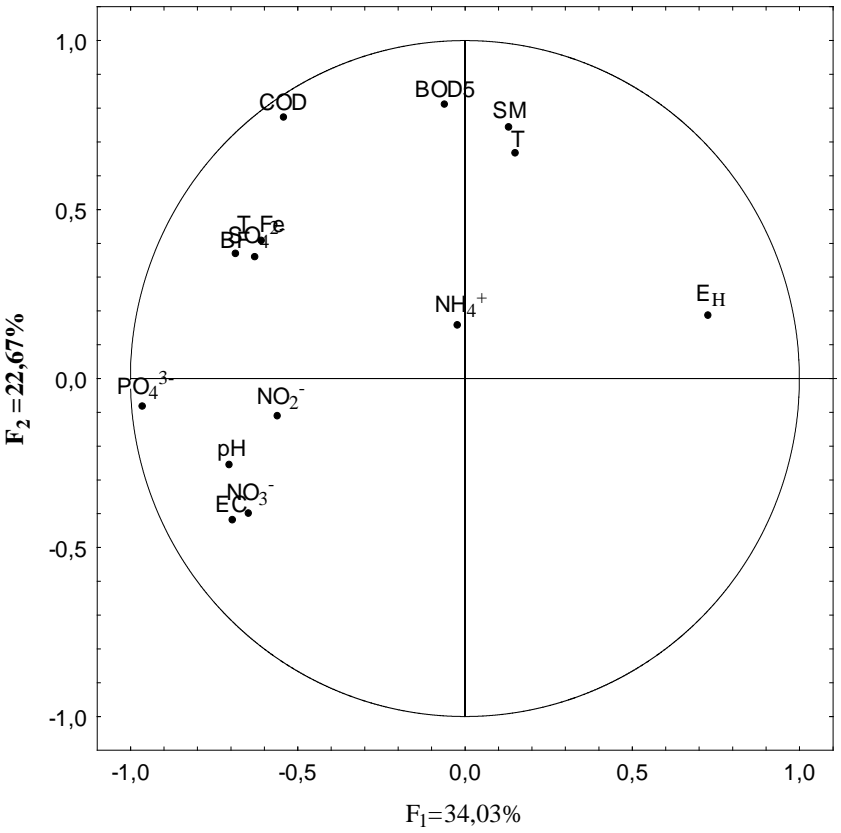

(a)

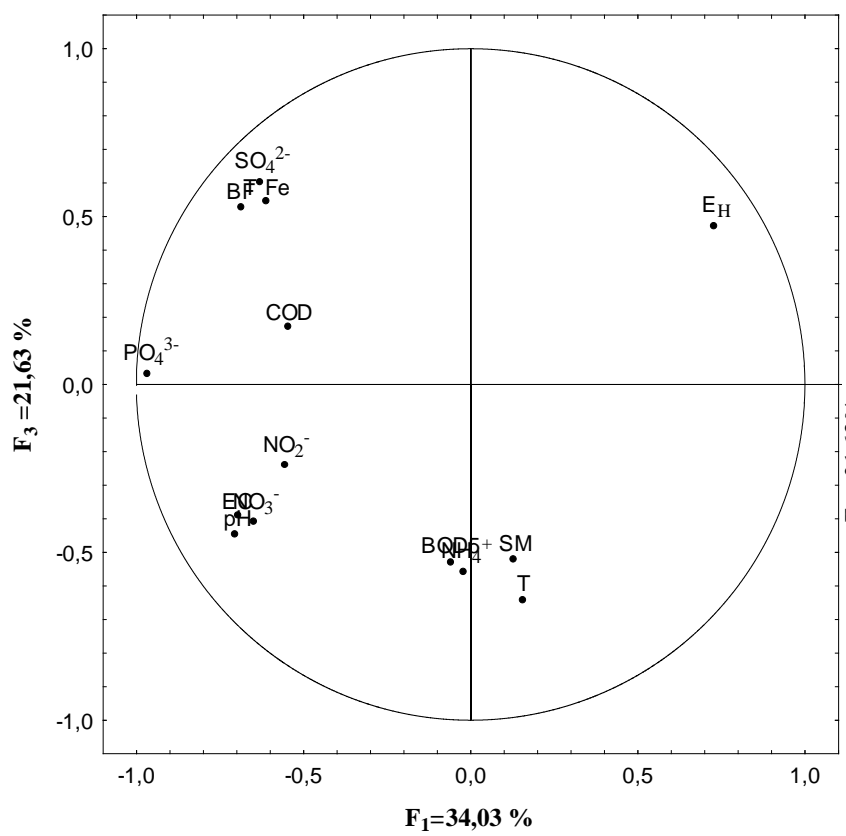

(c)

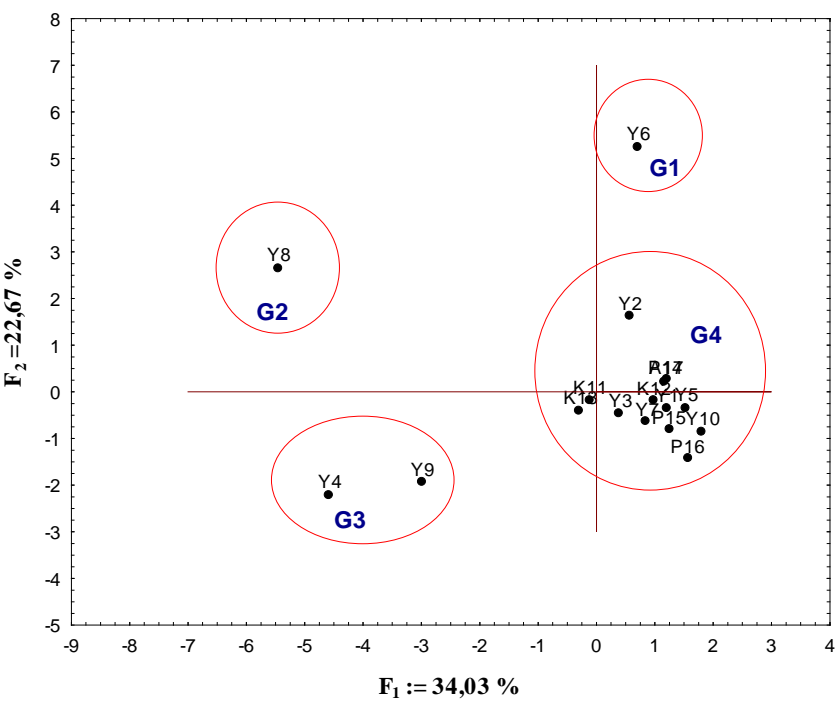

(b)

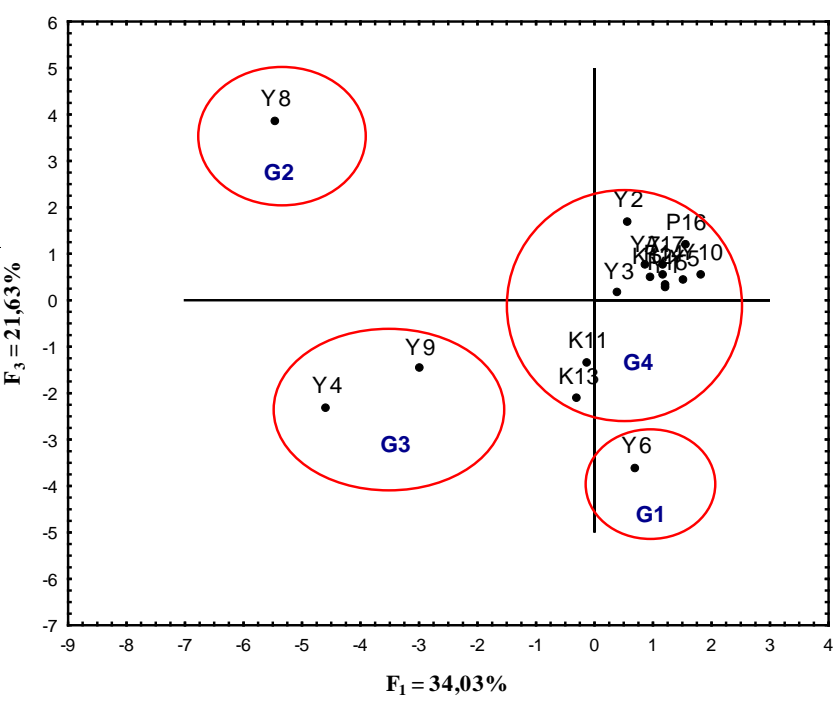

(d)

Figure 2. (a) Circle of community of the factorial design $\left(F_{1}-F_{2}\right)$; (b) Statistical units of the factorial design $\left(F_{1}-F_{2}\right)$; (c) Circle of community of the factorial design $\left(F_{1}-F_{3}\right)$; (d) Statistical units of the factorial design $\left(F_{1}-F_{3}\right)$.

2 relates to ILDS with high temperature, rich in COD, iron and in $\mathrm{SO}_{4}^{2-}$, such as soap factory Y8; Group 3 corresponds to the alkaline, mineral-bearing ILDS and rich in $\mathrm{PO}_{4}^{3-}, \mathrm{NO}_{2}^{-}$, and $\mathrm{NO}_{3}$ (soap factories $\mathrm{Y} 4$ and $\mathrm{Y} 9$ ); Group 4 concerns ILDS with low pollutants mentioned above, i.e. soap factories Y1, Y2, Y3, Y5, Y7, Y10, K11, K12, K13, P14, P15, P16 and A17.

Application of Ascending Hierarchical Classification (AHC) to the result of the PCA permits to specify clearly the above Groups. Thus three (03) groups 
were distinguished in the following way (Figure 3). Y2 and group 2 gather and form the main group II. Group 3 and Group 4 gathered to give only one main group, i.e. group III. Finally, three main Groups can be define as following: main Group I corresponds Y6 soap factory; main Group II includes soap factories Y8, Y2 and main Group III is made up from soap factories: Y1, Y3, Y4, Y5, Y7, Y9, $\mathrm{Y} 10, \mathrm{~K} 11, \mathrm{~K} 12, \mathrm{~K} 13, \mathrm{P} 14, \mathrm{P} 15, \mathrm{P} 16$ and A17. This result is not enough different from those retrieved from PCA, which revealed four types of pollution generated by the liquid discharges of soap factories. Thus, the seventeen soap mills studied are grouped into three main groups according to the similar physicochemical quality of their releases.

\section{Conclusion}

The results of this work show the need to evaluate the level of pollution due to industrial rejection in Abidjan area. These results point out an alarming situation. Except the temperature, most of the other parameters of rejection have concentration which is beyond the national required level. Thus, fifteen (15) out of seventeen (17) selected soap and cosmetic industries (88.00\%) discharge their effluents into the Ebrié lagoon without prior treatment. Those effluents are difficultly biodegradable. These soap industries do not have treatment stations or use powerless treatment processes. Moreover, they have very heterogeneous effluents due to both the specific raw materials used for the formulation and above all the non-respect of the laws that regulate their corporation. Moreover, these soap factories are classified into three groups according to the physicochemical quality of their releases: Group I (Y6), Group II (Y8, Y2) and Group III (Y1, Y3, Y5, Y7, Y9, Y10, K11, K12, K13, P14, P15, P16 and A17). Overall, the releases are sources of nutritive, organic and chemical pollution. Also, these discharges exhibit very high and non-biodegradable organic charges which are certainly linked to the use of surfactants that are difficult to biodegrade in the formulation of

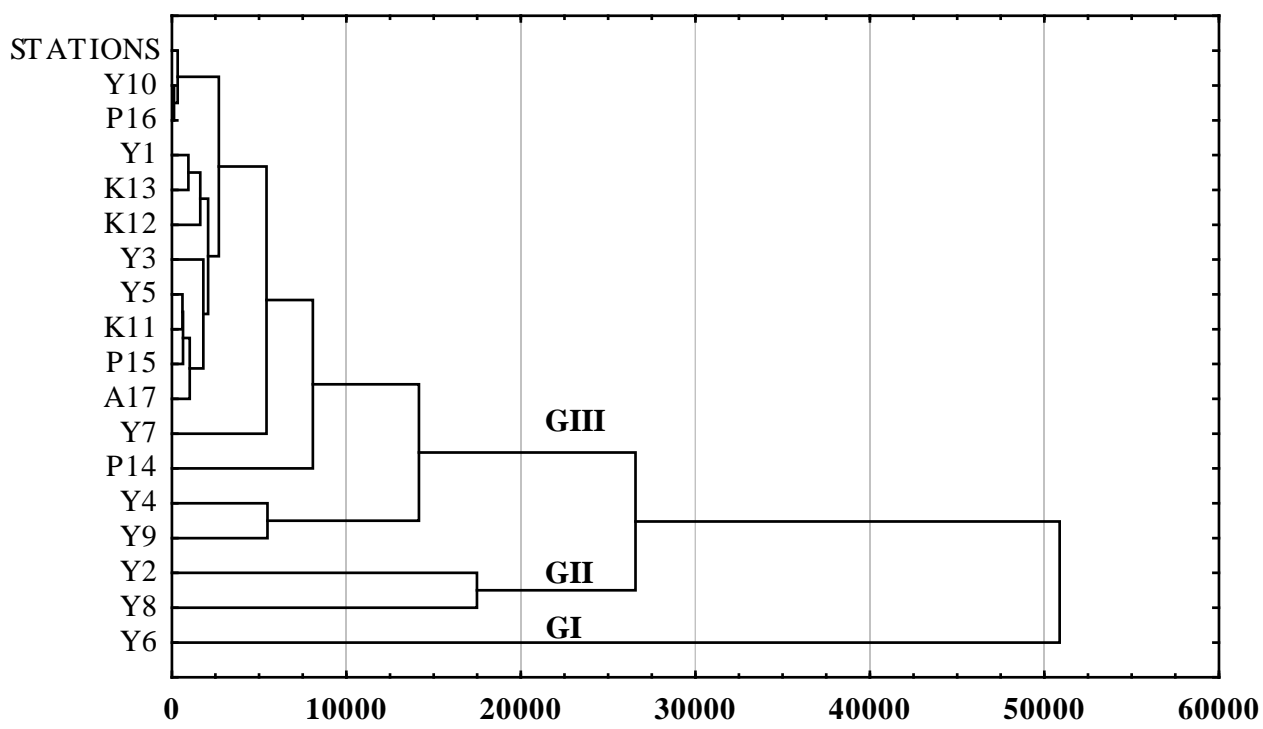

Figure 3. Ascending hierarchical classification of the studied soap factories. 
detergents and cosmetics. The rejection of these micro pollutants without prior treatment affects the receiving environment. The ILDS, thus, highly contribute to the pollution of the Ebrié lagoon. In response to this sad remark induced by industrial soap liquid discharges, appropriate solutions must be found in terms of protection of the Ebrié lagoon and treatment process of these ILDS before the rejection of their waste. Republic of Côte d'Ivoire must make sure that industrial soap liquid waste is effectively well managed by soap factories. For us, a characterization of the anionic surfactants in ILDS is envisaged because of its wide use as an active ingredient in the formulation of any detergency product and cosmetics. A process for treating these anionic surfactants is envisaged in order to propose it to the soap industries who's ILDS are rich in these micro pollutants.

\section{Acknowledgements}

The authors thank the state institutions in charge of environment and drainage (ANDE, CIAPOL, and ONAD). They would like to express their sincere thanks to CIAPOL, through the Division of Inspection Services for Classified Installations (D/CIIS) and the Central Environmental Laboratory of the Ivorian Anti-Pollution Center (CEL-CIAPOL) for their contribution to the success of this work.

\section{References}

[1] Ahoure Alban, A.E. and Paulin, T.A. (2009) Bilan diagnostic de l'industrie ivoirienne. CAPEEC-CIRES, 37.

[2] Yoda, N. (2007) Politique de gestion des déchets industriels dans les entreprises du secteur privé à Abidjan. Thèse de Doctorat en Médecine, Université de Cocody, Abidjan, 107.

[3] Kablan N'guessan Hassy Joseph and Kouakou N'Goran Norbert (2013) Impact environnemental de la zone industrialo-portuaire (ZIP) d'Abidjan. European Scientific Journal, 9, 206-221.

[4] Adingra, A. (2011) Pollution en lagune Ebrié et ses impacts sur l'environnement et les populations riveraines. F. Tech. \& Doc. Vulg, 48-53.

[5] United Nations (2006) World Urbanization Prospects: The 2005 Revision. United Nations, New York, 210.

[6] Institut National de la Statistique (2015) Estimation à partir du RGPH 1998 de la répartition de la population des communes d'Abidjan selon le sexe. 2.

[7] Afnor (2001) Qualité de l'eau, Eléments majeurs-autres éléments et composés minéraux. Aubenas Ardèche, 6e Edition, 635.

[8] Wolff, M. (2003) Apports de l'analyse géométrique des données pour la modélisation de l'activité. In: Sperandio, J.C. and Wolff, M., Eds., Formalismes de modélisation pour Panalyse du travail et Pergonomie, Presses Universitaires de France, Paris, 195-227. https://doi.org/10.3917/puf.boppe.2003.01.0195

[9] Anonyme (2008) Arrêté $\mathrm{n}^{\circ}$ 2008-1164 du 04 novembre 2008, portant sur la réglementation des rejets et émissions des installations classées pour la protection de l'Environnement.

[10] Rodier, J. (2009) L'Analyse de l'Eau: Eaux Naturelles, Eaux Résiduaires et Eaux de Mer. 9th Edition, DUNOD, Paris, 1384. 
[11] Claude, S. (2001) Oléagineux, Corps Gras, Lipides. Oilseeds and Fats, Crops and Lipids, 8, 134-135. https://doi.org/10.1051/ocl.2001.0134

[12] Dongo, K.R., Niamke, B.F., Adje, A.F., Britton, B.G.H., Nama,L.A., Anoh, K.P., Adima, A.A. and Atta, K. (2013). Impacts des effluents liquides industriels sur l'environnement urbain d'Abidjan-Côte D'Ivoire. The International Journal of Biological and Chemical Sciences, 7, 404-420. https://doi.org/10.4314/ijbcs.v7i1.36

[13] Affian, K., et al. (2008) Flux de la matière en suspension du fleuve Comoé de la zone littorale ivoirienne. Revue du CAMES, 6, 88-93.

[14] Zayani, et al. (2002) Etude de la cinétique de dégradation photocatalytique du colorant commercial azoïque (Jaune Cibacron FN-2R). Proceedings of International Symposium on Environmental Pollution Control and Waste Management, Tunis, 838-845.

[15] Moctezumaa (2007) Photocatalytic Degradation of Methyl Parathion: Reaction Pathways and Intermediate Reaction Products. Journal of Photochemistry and Photobiology A: Chemistry, 186, 71-84.

[16] Bostrom, B. (1984) Potentiel Mobility of Phosphorus in Different Types of Lake Sediment. Internationale Revue der Gesamten Hydrobiologie, 69, 457-474. https://doi.org/10.1002/iroh.19840690402

[17] Anonyme (2007) Décret $\mathrm{N}^{\circ}$ 2007-491 du 29 mars 2007, interdisant la commercialisation et l'utilisation des phosphates dans les détergents textiles domestiques en Suisse.

[18] INERIS (2012) Fiche de données toxicologiques et environnementales des substances chimiques. 110 .

[19] Chambers, P., et al. (2001) Nutrients and Their Impact on the Canadian Environment. Environ. Canada, 241.

[20] Li, et al. (2000) Assessment of the Pollutant Elimination Efficiency by Gas Chromatography/Mass Spectrometry, Liquid Chromatography-Mass Spectrometry and Tandem Mass Spectrometry Comparison of Conventional and Membrane-Assisted Biological Wastewater Processes. Journal of Chromatography A, 889, 155-176.

\section{Scientific Research Publishing}

Submit or recommend next manuscript to SCIRP and we will provide best service for you:

Accepting pre-submission inquiries through Email, Facebook, LinkedIn, Twitter, etc. A wide selection of journals (inclusive of 9 subjects, more than 200 journals)

Providing 24-hour high-quality service

User-friendly online submission system

Fair and swift peer-review system

Efficient typesetting and proofreading procedure

Display of the result of downloads and visits, as well as the number of cited articles

Maximum dissemination of your research work

Submit your manuscript at: http://papersubmission.scirp.org/

Or contact gep@scirp.org 